\title{
MECHANICALPROPERTIES OF WELDED JOINTS OF 1.3964 STEEL FOR COMPUTER AIDED ENGINEERING (CAE) PURPOSES
}

\author{
Radosław Kiciński1(D, Wojciech Jurczak² (D) \\ Polish Naval Academy, Faculty of Mechanical and Electrical Engineering, Śmidowicza 69 Str., 81-127 \\ Gdynia, Poland; e-mail: r.kicinski@amw.gdynia.pl,w.jurczak@amw.gdynia.pl; ORCID ID: 10000-0003- \\ $-3490-1301,20000-0002-1608-7249$
}

\begin{abstract}
The article presents the study of mechanical properties of welded steel from which the hull of a modern mine destroyer was made. Keeping the tightness of ship compartments during operation depends on the strength of these joints. The results of testing the mechanical properties of 1.3964 steel and its welded joints subjected to a static tensile test were presented, and a Johnson Cook material model was proposed. The material model can be used in CAE (Computer Aided Engineering) simulations related to hull strength analysis.
\end{abstract}

Keywords:

Computer Aided Engineering, austenic steel, true material characteristic, welding.

Research article

(C) 2020 Radosław Kiciński, Wojciech Jurczak This is an open access article licensed under the Creative Commons Attribution-NonCommercial-NoDerivatives 4.0 license (http://creativecommons.org/licenses/by-nc-nd/4.0/) 


\section{INTRODUCTION}

Operational problems of offshore structures, also made of austenitic stainless steel, are caused not only by the impact of the marine environment causing corrosion, but also by operating conditions associated with the impact of operational stresses. The strength of the load-bearing elements of each structure ensures its operational reliability and operational safety. The marine structure consists of elements that are most often joined as a result of welding. The strength of welded joints depends on many factors, but primarily on the mechanical properties of the welded structural material, the type of binder used, the method and welding parameters.

Austenitic alloys are the most popular stainless steels because of their excellent ability to plastic deformation, corrosion resistance and weldability [1], which is why they are often used in shipbuilding. They are non-magnetic in the annealed condition, which is why they are intended, for example, for the construction of modern mine destroyers. Mine destroyer hulls are built of non-magnetic steel ensuring low characteristics of ship's physical fields.

Prefabrication, assembly of sections, blocks and hull takes place in a special hall equipped with monitoring systems and specialized filtering and controlling devices, including cleanliness and air temperature, as well as preventing iron filings and other external contaminants from entering [4].

In shipbuilding practice, the method of welding austenitic steels is GTAW (Gas Tungsten Arc Welding), also known as the TIG (Tungsten Inert Gas) or WIG (Wolfram Inert Gas) method. The energy necessary to melt the metal is supplied by an electric arc struck and held between the tungsten or tungsten alloy electrode and the welded element in an inert gas atmosphere. Stainless steels are always welded with direct current at negative polarity (DCEN — Direct Current Electrode Negative or DCSP - Direct Current Straight Polarity). Under these conditions, the electron flux hits the welded piece, which increases fusion, while the tungsten oxide $\left(2 \% \mathrm{ThO}_{2}\right)$ tungsten oxide electrode usually consumes slightly. Welding parameters are voltage, welding current, welding speed and shielding gas flow. If a binder is used, it is either in the form of bare rods or in the form of coils for automatic welding. The inert gas flow, which protects the arc zone from the surrounding air, allows the arc to remain very stable. Depending on the welded material, the shielding gas consists mainly of a mixture of argon (Ar), helium (He) and hydrogen $\left(\mathrm{H}_{2}\right)$ [10]. The correct selection of welding parameters for thermal joining of particular austenitic steel is usually the know-how of the contractor, which is obtained during multi-variant trials and tests. 
During welding, care should be taken to preserve welding technology, which has a direct impact on the quality of joints.

The 1.3964 non-magnetic steel also designated as EN X2CrNiMoNNb 21-16-5-3 is well weldable and resistant to sea water up to $40^{\circ} \mathrm{C}$, as well as intergranular stress corrosion [8]. However, the correct chemical composition of the binder should be chosen to ensure adequate strength and good corrosion resistance. The chemical composition of 1.3964 steel is given in the tab. 1 .

Tab. 1. Chemical composition of 1.3964 steel

\begin{tabular}{|c|c|c|c|}
\hline \multirow{2}{*}{\multicolumn{2}{|c|}{$\frac{E N-10088}{A S T M X M}$}} & \multicolumn{2}{|c|}{ 1.3964/ X2CrNiMoNNb 21-16-5-3 } \\
\hline & & & 19 \\
\hline \multicolumn{2}{|c|}{$\begin{array}{c}\text { Chemical } \\
\text { composition }\end{array}$} & according to the manufacturer [7] & according to the metallurgical certificate \\
\hline C & $\%$ & $\max 0.03$ & 0.012 \\
\hline Mn & $\%$ & $4-6$ & 4.42 \\
\hline $\mathbf{C r}$ & $\%$ & $20-21.5$ & 20.32 \\
\hline $\mathbf{N i}$ & $\%$ & $15-17$ & 15.46 \\
\hline Mo & $\%$ & $3-3.5$ & 3.15 \\
\hline Nb & $\%$ & $\max 0.25$ & 0.12 \\
\hline $\mathbf{N}$ & $\%$ & $<0.11$ & 0.305 \\
\hline $\mathbf{F e}$ & $\%$ & residue & residue \\
\hline Si & $\%$ & - & 0.36 \\
\hline $\mathbf{P}+\mathbf{S}$ & $\%$ & $\max$ & $19+00004$ \\
\hline
\end{tabular}

Binder recommended by the manufacturer for welding 1.3694 steel is 1.3954 and 1.3984 [6]. For the tests described in this article, samples welded manually and semi-automatically with 1.3954 binder were used.

\section{MATERIALS AND METHODS}

Strength tests were carried out using the MTS 810 machine in accordance with the standard [9]. Properly prepared specimens (fig. 1) were stretched at a rate of $0.12 \mathrm{~mm} / \mathrm{s}$. During tests with an interval of $0.2 \mathrm{~s}$, digital images of the sample surface were recorded with contrast applied for the method of digital image correlation (DIC) using images recorded simultaneously by at least two cameras.

Then these images are processed and used to calculate the deformation fields in the vicinity of the place where the original deformation was located. The 3D 
method was chosen because of the non-flat surface of the samples due to the presence of welds and in order to avoid the influence of displacements in a direction perpendicular to the surface of the sample, to which the 2D method (using one camera) is sensitive. Before the tests, the system was calibrated based on photos of a calibration grid of known geometry oriented at different angles to the cameras. These photos were used to calculate the relative position of cameras and samples and to scale pixels per mm.

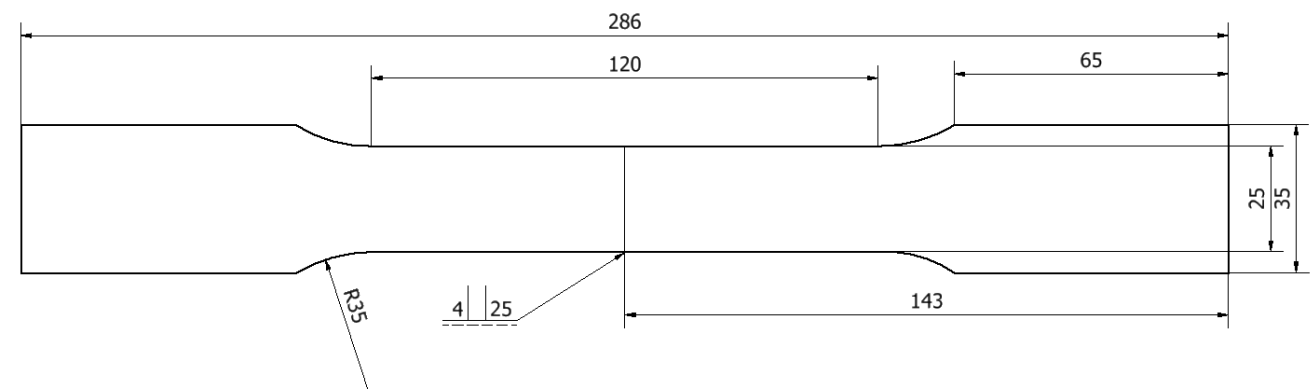

Fig. 1. Specimen dimensions and technical drawing

The measurement of the longitudinal component of the deformation of the area for which the highest values were observed at the final stage of the tests was used to calculate the actual stress in the way presented in [4] as method II. That article showed a high compliance of the method in comparison with a much more complicated method (method I) based on the simultaneous measurement of narrowing of both side surfaces of the sample using 4 cameras. The actual stress was calculated from the formula:

$$
\sigma=\frac{F}{A_{0}} e^{\varepsilon_{x x}}
$$

where:

$F \quad$ - force;

$A_{0} \quad$ - initial cross-sectional area (outside the weld);

$\varepsilon_{x x}$ - longitudinal component of logarithmic strain tensor.

\section{RESULTS}

\section{Base material}

For 1.3964 steel specimens with a rectangular cross-section, the method of taking a sample from a sheet metal along or transversely to the rolling direction has 
an effect on strength properties. Based on the engineering stretching curve, real characteristics were developed in accordance with the methodology contained in [11] and presented in fig. 2 and in tab. 2.

a)

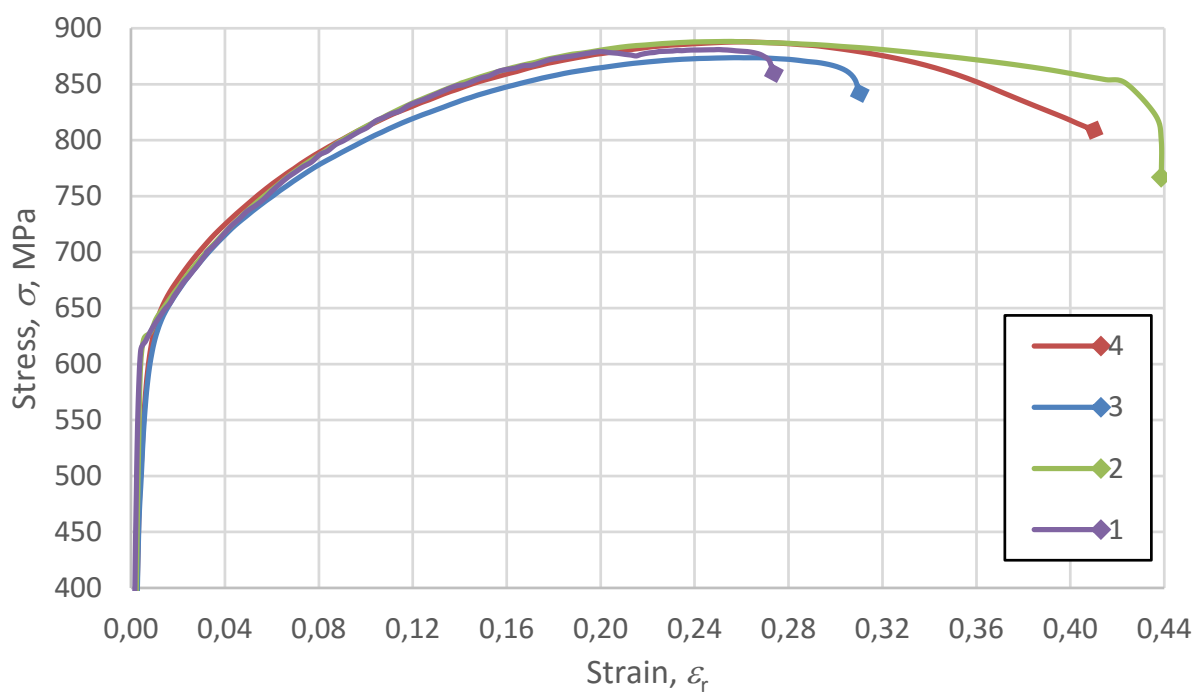

b)

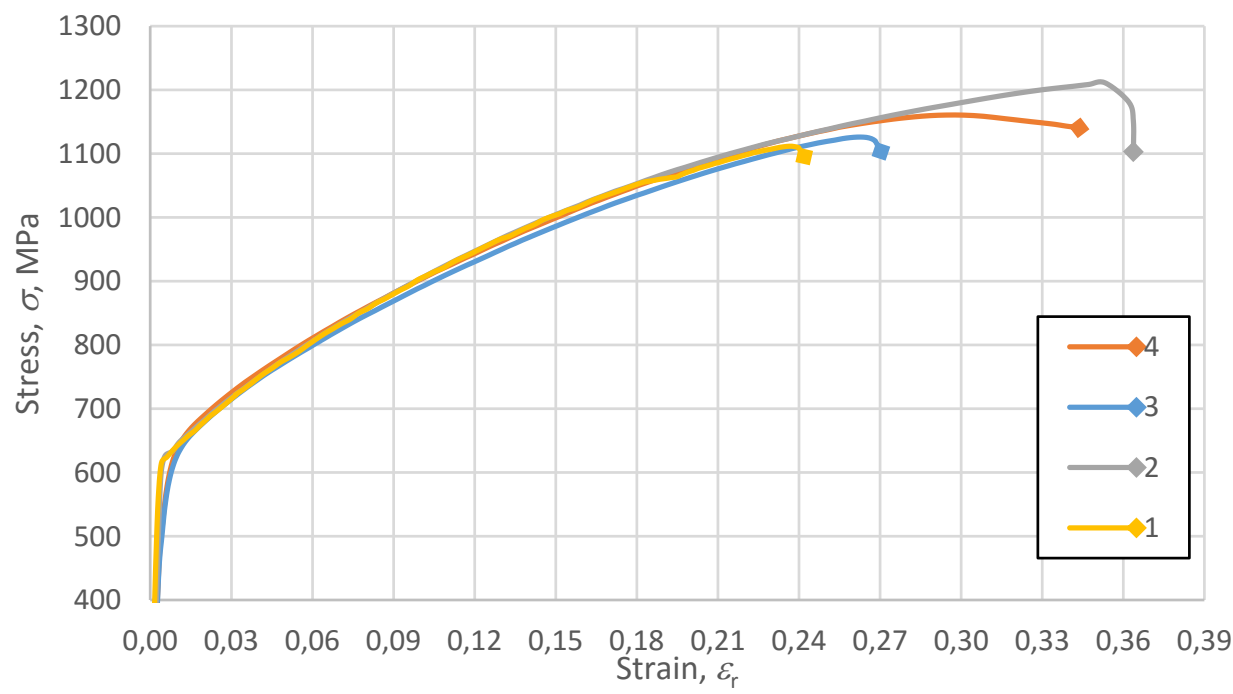

Fig. 2. Selected characteristics of 1.3964 austenitic steel for flat specimens taken along the rolling direction (2 and 4) and perpendicular to the rolling direction (1 and 3): a) nominal, b) true 
Tab. 2. Summary of mechanical properties for flat 1.3964 steel samples taken along and perpendicular to the rolling direction

\begin{tabular}{|c|c|c|c|c|c|}
\hline Steel 1.3964 & $\begin{array}{l}\text { Young } \\
\text { modulus }\end{array}$ & Yield point & Yield strain & $\begin{array}{l}\text { Ultimate } \\
\text { strength }\end{array}$ & $\begin{array}{l}\text { Ultimate } \\
\text { strain }\end{array}$ \\
\hline $\begin{array}{l}\text { Position to the rolling } \\
\text { direction }\end{array}$ & $E, \mathrm{GPa}$ & $R_{\mathrm{e}}, \mathrm{MPa}$ & $\varepsilon_{\mathrm{n},-}$ & $R_{\mathrm{m}}, \mathrm{MPa}$ & $\varepsilon_{\mathrm{r},}-$ \\
\hline perpendicularly & \multirow{3}{*}{221.0} & 569.6 & 0.043 & 1126.4 & 0.3285 \\
\hline 1/perpendicularly & & 615.1 & 0.042 & 1111.7 & 0.2365 \\
\hline $3 /$ perpendicularly & & 501.3 & 0.044 & 1126.0 & 0.2615 \\
\hline \multicolumn{2}{|l|}{ Average } & 562 & 0.0042 & 1121.5 & 0.2615 \\
\hline along & \multirow{3}{*}{215.2} & 533.4 & 0.0042 & 1158.1 & 0.3581 \\
\hline 2/along & & 625.5 & 0.0054 & 1211.1 & 0.3533 \\
\hline 4/along & & 557.7 & 0.0055 & 1160.7 & 0.2945 \\
\hline \multicolumn{2}{|l|}{ Average } & 572.2 & 0.0048 & 1176.6 & 0.3353 \\
\hline
\end{tabular}

Rolling direction has an effect on the plastic properties of 1.3964 base steel material. At a similar strength limit $R_{\mathrm{m}}=880-900 \mathrm{MPa}$ for both rolling directions, the deformation was reduced by about $30 \%$ for samples taken perpendicular to the rolling direction (fig. $2 a$ ). Fig. 2 b shows the actual strength characteristics verified by the DIC method, where a change in the nature of the course after exceeding the yield point was noted, resulting from the change in the cross-sectional area of the tested sample. The use of the DIC method illustrates the increase in the strength limit $R_{\mathrm{m}}$ by $250 \mathrm{MPa}$ for samples taken perpendicular to the rolling direction and by $295 \mathrm{MPa}$ for samples taken along the rolling direction in relation to the nominal characteristics.

Referring to round samples, in tests of rectangular cross-section samples there was less variation in plastic properties (from 30\% to 5\%) between samples taken along and perpendicular to the rolling direction with a similar increase in material strength [3]. Therefore, for comparative tests for welded joints, nominal and true characteristics were determined, and then the Johnson - Cook (JC) model was proposed in form [2]:

$$
\sigma=\left(A+B \varepsilon^{n}\right)
$$

where:

$$
\begin{aligned}
& \sigma \text { - stress; } \\
& A \text { - material constant; } \\
& B \text { - strengthening parameter; }
\end{aligned}
$$


$\varepsilon$ - reduced plastic strain;

$n$ - exponent of strengthening.

Constants for the model were obtained using the MATLAB environment and a specially prepared calculation program. The JC model obtained by the program can be presented in the form of:

$$
\sigma=\left(302+1250 \varepsilon^{0,3334}\right), \mathrm{MPa}
$$

The thickness of the sheet metal from which the flat samples were cut was 4,6 , and $8 \mathrm{~mm}$, however, a much larger number of samples subjected to testing were samples that were taken from a $4 \mathrm{~mm}$ thick sheet, because this thickness is dedicated to the mine destroyer's hull. The values of the determined Young's modules are close to the values characteristic for steel, which allows the tensile test to be considered correct.

Tab. 2 and fig. 2 show the mechanical properties read from true characteristics for flat samples taken from a steel sheet dedicated to the hull structure plating. They show that with a constant yield strength value in relation to the nominal values (about $550 \mathrm{MPa}$ ), the tensile strength limit changes. The average tensile strength limit is $1150 \mathrm{MPa}\left(R_{\mathrm{m}}\right.$ approx. $850 \mathrm{MPa}$ nominal) with strain reduced by $20 \%$ on average.

By comparing the mechanical properties of true characteristics for flat samples, it is difficult to show the influence of the rolling direction on the results, since there is no large dispersion in the values of yield strength and tensile strength, while for samples taken along the rolling direction, an increase in maximum elongation and strain is visible.

Comparison of the mechanical properties of the tested steel indicates that for samples taken perpendicular to the rolling direction, the strength limit is reduced by $4.7 \%$ with a reduced strain equal to $\varepsilon=2.01 \%$, the yield strength decreased by $1.78 \%$ with the corresponding strain reduced by $\varepsilon=16.5 \%$ in relation to the mechanical properties of the samples taken perpendicular to the rolling direction occurs.

For flat 1.3964 steel samples, the difference between the tensile strength limit determined from true characteristics is $35.5 \%$ larger for samples taken along the rolling direction and $28.9 \%$ larger for samples taken perpendicular to the rolling direction. 


\section{Welded joints}

The next stage of the work was to examine the strength properties of welded joints. For this purpose, a set of samples was prepared, which was subjected to a static tensile test. Welding of $4 \mathrm{~mm}$ thick steel was carried out at Remontowa Shipbuilding SA in order to obtain identical welded joints as on the 258 project hull structure. Welding was performed by two methods of welding inert gas shielding (TIG) manually and semi-automatically. This approach should reduce the heat impact zone due to minimizing the heat exposure time for welding.

Then a static tensile test in order to obtain the actual material curves using DIC and the methodology described in [11] was carried out. Selected curves for the tests of welded joints made using the TIG method compared to the proposed Johnson Cook material model (3) are presented (fig. 3).

\section{a) TIG semi-automatic}

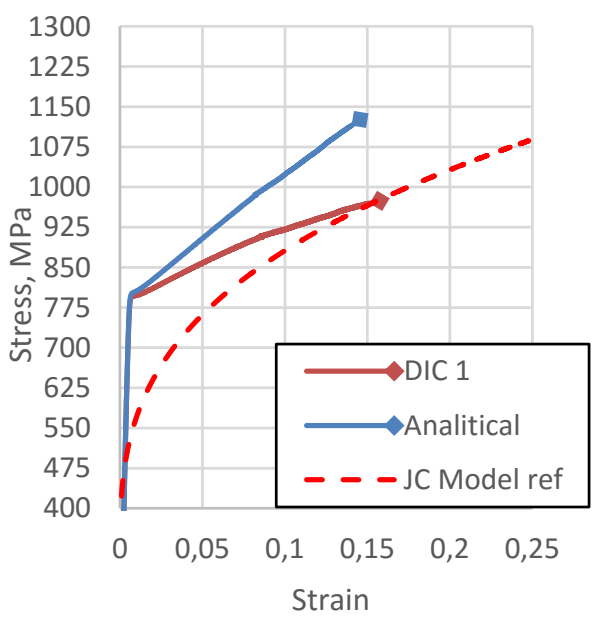

b) TIG manual

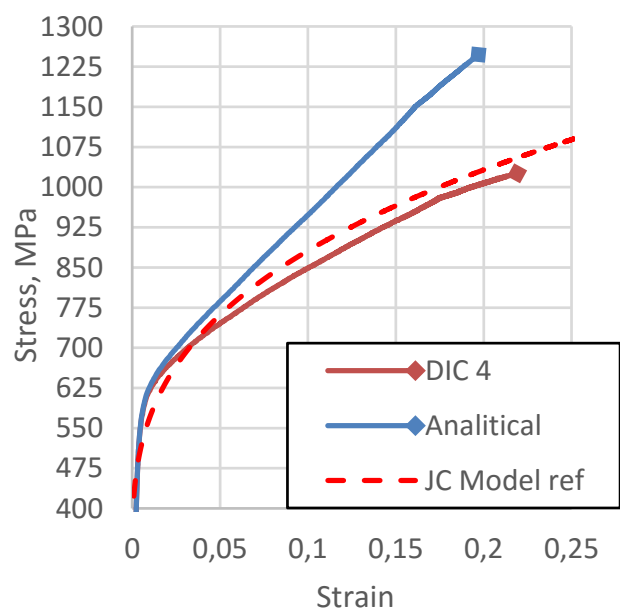

Fig. 3. Characteristics obtained by the DIC and analytical method of welded 1.3964 steel joints

Samples of welded joints were usually damaged in the base material (NM), outside the weld area (fig. 4). Cracking of welded joints took place outside the weld, the fusion line and the heat affected zone (HAZ). Samples cracked in the base material, which shows that the strength of the weld itself is greater than the welded steel. 


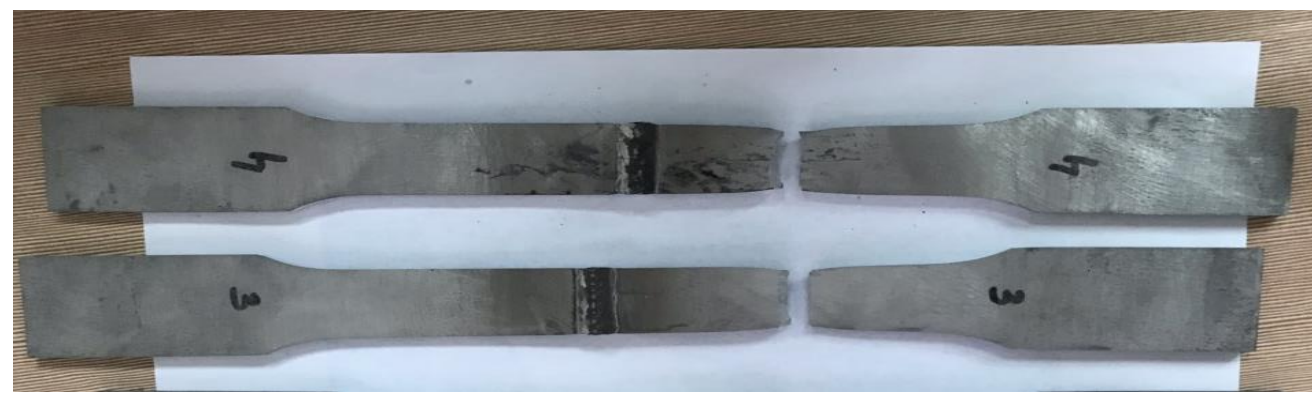

Fig. 4. Examples of samples for which the crack occurred in base material

However, for one case a crack was noted not in the base material. Based on the hardness tests, the width of the heat affected zone was determined to be approximately $10 \mathrm{~mm}$ from the edge of the weld. The fracture occurred on the zone border (fig. 5). The course of the stretching curve for the discussed case differs from the other samples and the material model. Therefore, it was decided to compare the material characteristics of the reference (non-welded) sample with welded samples. The results are shown in fig. 6.

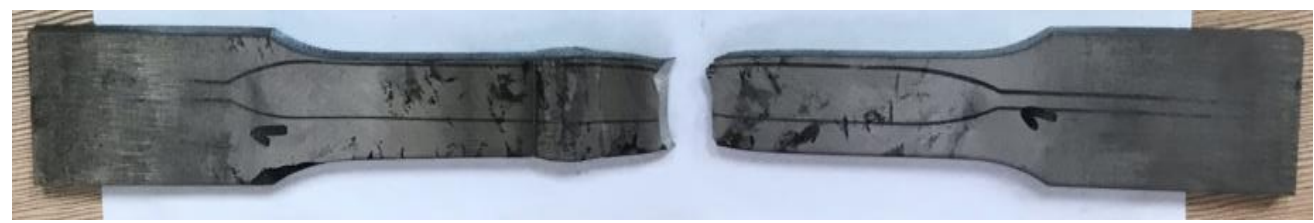

Fig. 5. Sample damaged at the edge of a heat affected zone

Knowing the true curves for welded joints, the JC model for welded joints was calculated using the procedure developed in MATLAB. Material constants for the weld model were proposed in the form:

$$
\sigma=\left(729+689 \varepsilon^{0,555}\right), \mathrm{MPa}
$$

The curve fitting developed by the program is shown in fig. 7, while a comparison of the base material model with the welded joint model is shown in fig. 8. 

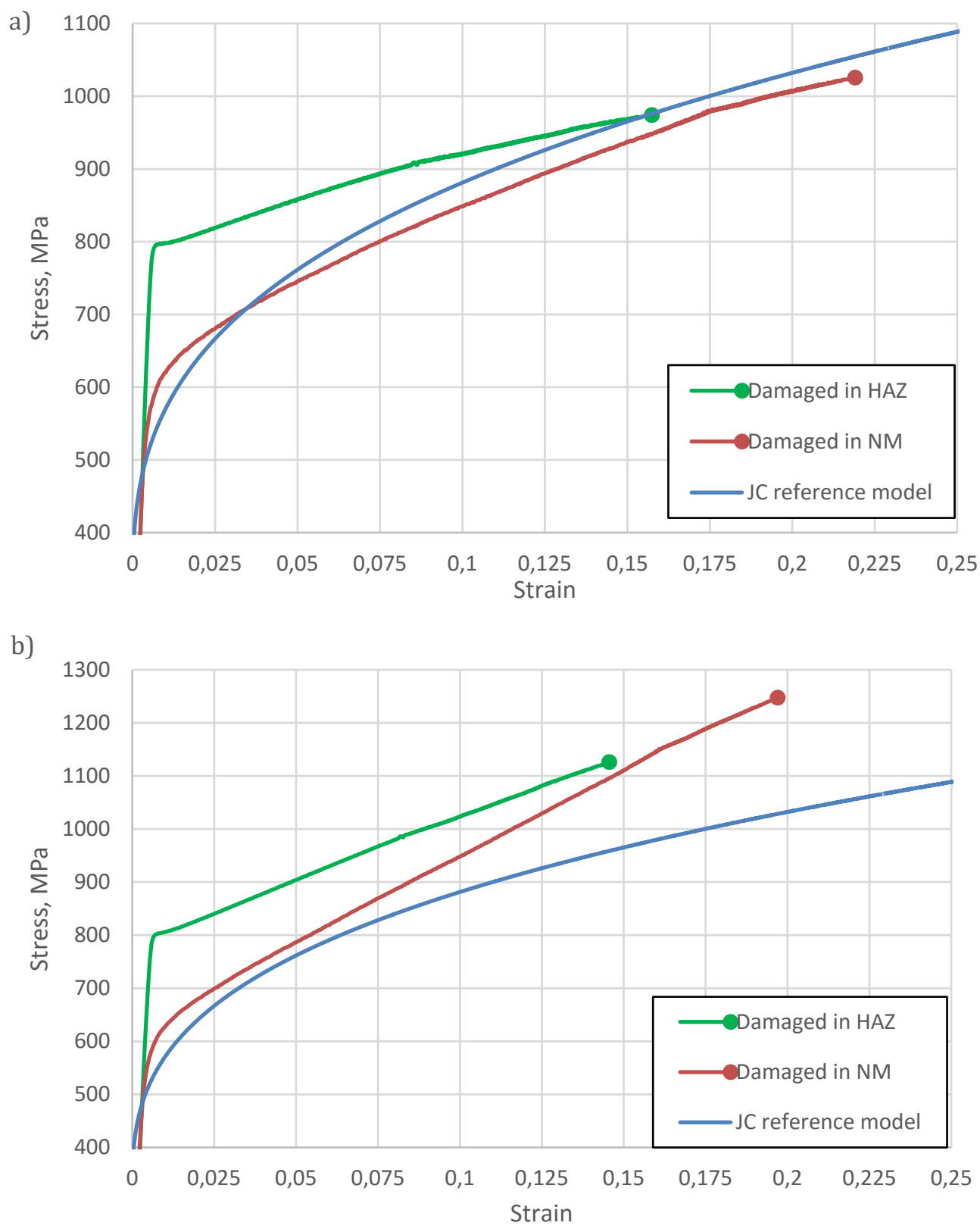

Fig. 6. Comparison of material characteristics determined by the DIC (a) and analytical (b) methods in relation to the JC model (3) 


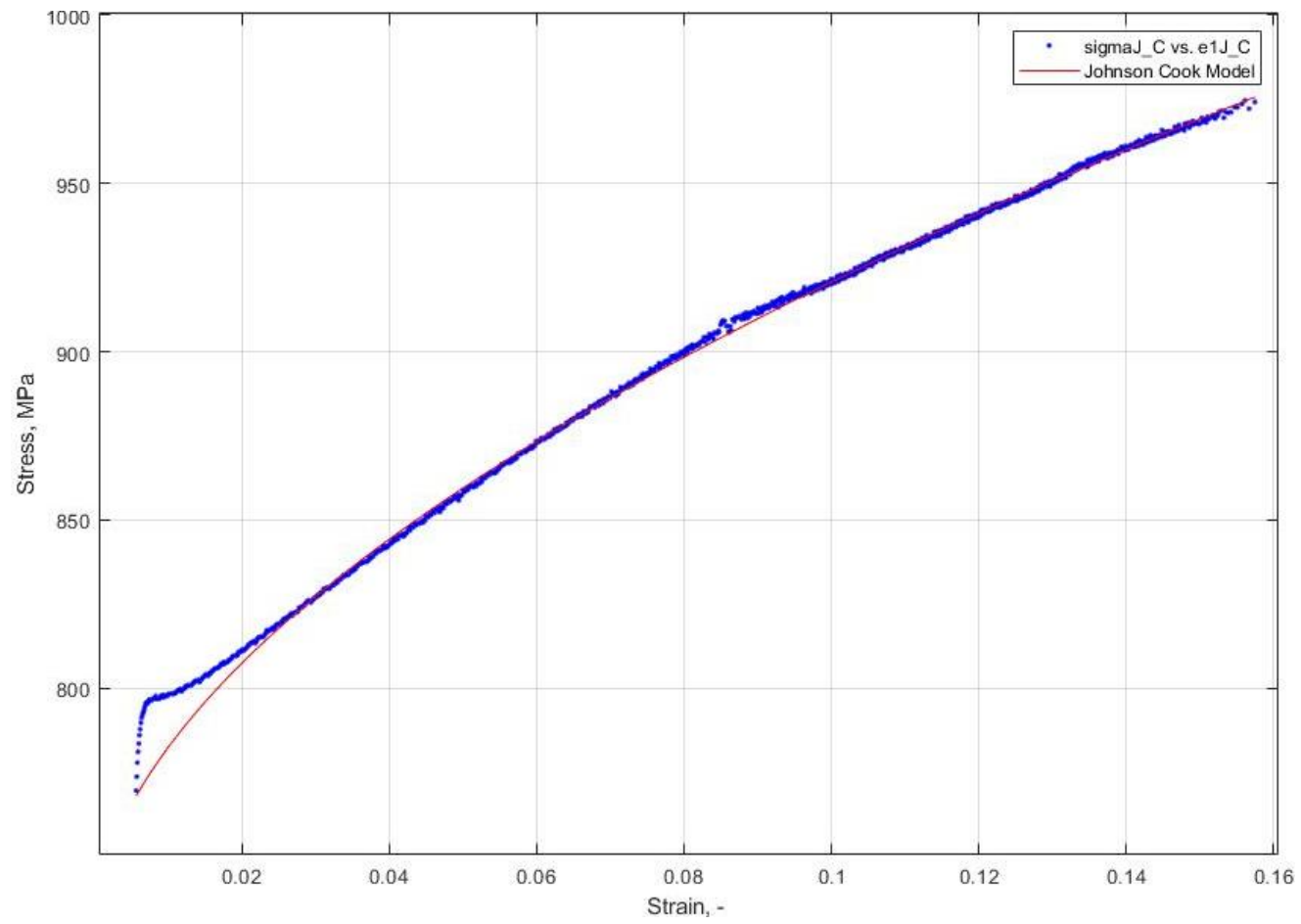

Fig. 7. Curve fitting for the material model developed in MATLAB

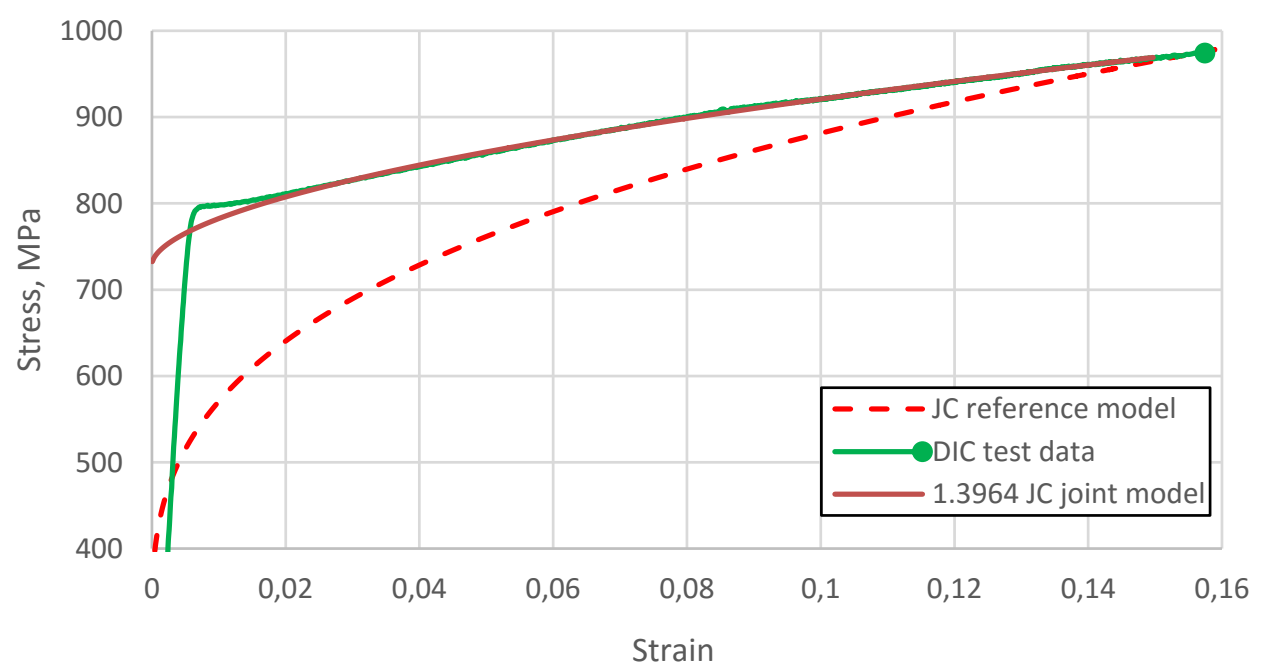

Fig. 8. Material curves developed for the needs of CAE welded joints strength analysis 


\section{SUMMARY}

The article presents tests of mechanical properties of 1.3964 steel and its welded joints. Johnson - Cook material model for welded joints was proposed. Despite the differences in the welded joint model from the base material, its usefulness may be necessary in specific cases for significant welded joints of a structure. Designers should be aware of the differences arising from the course of material curves during calculations using CAE.

Tests of mechanical properties of welded joints made using the digital image correlation method indicated a yield strength for welded joints at the level of 600 MPa for TIG manually and 800 MPa for TIG semi-automatically fig. 6.

The strength limit depends on the calculation methodology used. In the case of DIC it coincides with the values related to the reference sample, however, it refers to a different strain. In the case of analytical methodology, it is higher by a maximum of $200 \mathrm{MPa}$ in relation to the theoretical strength limit, maintaining relatively high plastic deformations. The value of plastic deformation of welded joints meets the required Polish Register of Shipping.

The cracking area of the tested welded joints, which took place in the base material, showed that the strength of the welded joints (welds, penetration lines and heat affected zone) is greater than the strength of the base material. It follows that the material characteristics of the weld and base material should be of a similar nature. However, there are some differences resulting from the impact of welding temperature, because there was a decrease in the plasticity of welded steel by approx. $10-15 \%$, which is common when increasing the hardness of the material.

In addition, one should consider the validity of the methods used to determine the actual material characteristics. The article shows the difference between the analytical and DIC method (fig. 6). The discrepancies should be verified by a more thorough analysis of the DIC method and factors affecting its unreliability. However, in engineering practice, the JC model is sufficient, which coincides well enough with the results of experiments in the field of plastic strain up to $10 \%$.

\section{REFERENCES}

[1] Brózda J., New-generation austenitic steels used for power equipment with supercritical parameters and their welding, 'Bulletin of the Polish Welding Centre of Excellence', 2006, 5, pp. 40-48. 
[2] Johnson G. R., Cook W. H., A constitutive model and data for metals subjected to large strains, high strain rates and high, 'Proceedings of the Seventh International Symposium on Ballistics, 2009.

[3] Jurczak W., Zatorski Z., Szturomski B. et al., Wyznaczanie rzeczywistych dynamicznych charakterystyk wytrzymałościowych stali austenitycznej oraz stopów aluminium, sprawozdanie z pracy badawczej statutowej pk. Austenka [Determination of true and dynamic strength characteristics of austenitic steel and aluminum alloys, report on statutory research under the Austenka code — available in Polish], Publ. Polish Naval Academy, Gdynia 2019.

[4] Kolejne etapy budowy okrętów typu 'KORMORAN II' [Next stages of construction of 'KORMORAN II' ships - available in Polish], Remontowa Shipbuilding, [online], http://www.remontowarsb.pl/aktualnosci/kolejne-etapy-budowy-okretow-typu-kormoran-ii/ [access 02.04.2020].

[5] Kong L. Z., Shuai J., Zhou X. Y. et al., True stress-logarithmic strain curves test of pipeline steels using 3D digital image correlation, 'Optoelectronics and Advanced Materials - Rapid Communications', 2015, Vol. 9, No. 11-12, pp. 1380-1388.

[6] Lincoln Electric. Katalog materiałów spawalniczych Lincoln Electric [Lincoln Electric welding consumables catalog — available in Polish].

[7] Metalcor 1.3964, Alloy 50, Metalcor GmbH, Essen, Germany.

[8] Open the forge, Voestalpine BÖHLER Edelstahl GmbH \& Co KG catalog, 2019.

[9] Polish Norm PN-EN ISO 6892-1:2009. Metallic materials. Tensile testing, Part 1, Method of test at room temperature, Polish Committee for Standardization, 2009.

[10] Sosiński A., Spawanie metodq TIG nie tylko dla poczq̨tkujq̨cych [TIG welding not only for beginners - available in Polish], Warszawa 2013.

[11] Szturomski B., Inżynierskie zastosowanie MES w problemach mechaniki ciała stałego na przykładzie programu ABAQUS [Engineering application of FEM in problems of solid mechanics on the example of the ABAQUS program - available in Polish], Publ. Polish Naval Academy, Gdynia 2013.

\section{WŁAŚCIWOŚCI MECHANICZNE POŁĄCZEŃ SPAWANYCH STALI 1.3964}

\section{STRESZCZENIE}

W artykule przedstawiono wyniki badań właściwości mechanicznych połączeń spawanych stali, z której zostało wykonane poszycie kadłuba współczesnego niszczyciela min. Od wytrzymałości tych połączeń zależy utrzymanie szczelności przedziałów okrętowych w czasie eksploatacji. Zaprezentowano wyniki badań właściwości mechanicznych stali 1.3964 i jej połączeń spawanych poddanych statycznej próbie rozciągania oraz zaproponowano model materiałowy Johnson - Cook. 
Model materiałowy może zostać wykorzystany w symulacji komputerowej CAE obciążenia kadłuba okrętu wykonanego z badanej stali.

\title{
Słowa kluczowe:
}

komputerowe wspomaganie projektowania (CAE), stal austenityczna, rzeczywiste charakterystyki materiałowe, spawanie.

\author{
Article history \\ Received: $\quad 02.04 .2020$ \\ Reviewed: 16.04.2020 \\ Revised: $\quad 18.04 .2020$ \\ Accepted: $\quad 26.04 .2020$
}

